\title{
Kärlek och klasskamp över Atlanten
}

Aili och Runar Nordgrens revolutionära livsresa

Jag slår försiktigt in spikarna. Karin hjälper mig så det går ganska bra. Vi hänger opp Marx och Engels och Lenin och så Stalin. Och de hänger ganska bra. ${ }^{1}$

SÅ SKILDRAR BERÄTtAREN BREng i romanen Med hur han tillsammans med sin syster Karin hänger upp tavlor på väggarna i det nya hemmet efter en flytt. Flyttkarlen misstar de avporträtterade männen för släktingar, men ikonerna inom världskommunismen är något annat: de är hemmets husgudar. Brengs föräldrar är nämligen trosvissa kommunister. Det pågår krig i landet, men just nu är pappan hemma på permission och kan hälsa på sin familj i det stora huset med glänsande tegeltak som ligger så vackert i närheten av vattnet. Breng är berättarjaget i Ralf Nordgrens roman $M e d$, som är starkt färgad av hans barn- och ungdomserfarenheter som son till huvudpersonerna i denna artikel, kommunisterna Aili och Runar Nordgren.

Ålänningen Aili Salminen och österbottningen Runar Nordgren träffades och gifte sig i New York under den stora depressionen i början av I930-talet. De två unga migranterna rörde sig i stadens socialistiska kretsar och radikaliserades i Wall Street-kraschens långa och djupa skugga. Efter att ha återvänt till Finland vid olika tidpunkter i mitten av 1930-talet fick Aili och Runar Nordgren två barn. Under fortsättningskriget bodde familjen på Åland där Aili skrev sin första roman och ytterligare två barn föddes. Efter att Finland slutit fred med Sovjetunionen 1944 fick paret i uppgift att etablera det kommunistiska partiet och dess folkdemokratiska frontorganisationer på det mycket konservativa och antikommunistiska Åland. Från och med år 1947

I. Ralf Nordgren, Med, Helsingfors: Schildts I968, s. II. 
fortsatte parets folkdemokratiska funktionärsarbete, och i Ailis fall även hennes författarskap, i Helsingfors. Föreliggande artikel ställer deras liv fram till flytten till huvudstaden i centrum.

Att vara finlandssvensk socialist i USA på I930-talet och kommunist på Åland under I940-talet innebar på många sätt att man hade en mellanposition. De finlandssvenska emigranterna befann sig som grupp mellan sina finskspråkiga landsmän och sina svenska språkbröder, samtidigt som de likt alla andra europeiska utvandrare befann sig mellan den gamla och den nya världen. På Åland var Aili bokstavligen hemma, men den kommunistiska övertygelse hon och Runar bar med sig från sin migrantresa innebar att de avvek från majoriteten. Syftet med vår artikel är att belysa dessa mellanpositioner och granska Aili och Runar Nordgrens liv som ett möte mellan olika politiska, sociala, kulturella och historiska omständigheter. Samtidigt vill vi visa på de möjligheter till tanke och handling som paret Nordgren hade under I930- och I940-talen på båda sidor om Atlanten. I ett större perspektiv studerar vi sammanflätningen av global kommunism och personliga minoritetserfarenheter utgående från detta specifika par. Vad kan Ailis och Runars sammanflätande livshistoria, som präglas av rörlighet och radikalism, blottlägga beträffande kärlek och klasskamp på svenska?

Inga biografiska studier har gjorts vare sig om Aili eller Runar Nordgren. Litteraturvetaren Thomas Warburton behandlar kort Ailis författarskap i Åttio år finlandssvensk litteratur (1984) och i det stora översiktsverket Finlands svenska litteraturbistoria: Andra delen. I90o-talet (2000) presenteras hon endast med en liten porträttbild och tillhörande bildtext. I den uppdaterade och förkortade versionen av det senare verket, Finlands svenska litteratur: I9Oo-2OI2 (20I4), har Aili Nordgren helt fallit bort. ${ }^{2}$ Aili var svensk sekreterare för Samfundet Sovjetunionen-Finland I948-I96r och Runar Demokratiska Förbundet för Finlands Folks svenska sekreterare 1948-1976, men trots sina cent-

2. Thomas Warburton, Attio år finlandssvensk litteratur, Helsingfors: Schildts I984, s. 265-267; Michel Ekman, "Femtiotalsprosa II: folklivsskildring”, Clas Zilliacus (utg.), Finlands svenska litteraturhistoria: Andra delen. I9oo-talet, Helsingfors: Svenska litteratursällskapet i Finland \& Stockholm: Atlantis 200o, s. 243; Michel Ekman (red.), Finlands svenska litteratur I900-2012, Skrifter utgivna av Svenska litteratursällskapet i Finland 783, Helsingfors: Svenska litteratursällskapet i Finland 20I4. 
rala positioner inom den finlandssvenska folkdemokratiska rörelsen omnämns de inte, med ett obetydligt undantag, i de publikationer om klasskamp på svenska i Finland som utkommit under de senaste åren. ${ }^{3}$ Syftet med denna uppsats är dock inte att litteraturvetenskapligt skärskåda Ailis författarskap eller att utreda paret Nordgrens betydelse i de folkdemokratiska nätverken i efterkrigstidens Finland, utan att granska deras gränsöverskridande resa från sina respektive småbrukarhem till det konservativa Åland och livet som det finländska kommunistpartiets lokala representanter.

Förutom för sitt eget författarskap har Aili Nordgren omnämnts i en rad verk som syster till den mera kända författarinnan Sally Salminen. År 2019 utkom en biografi över Sally Salminen författad av Ulrika Gustafsson, och i den figurerar Aili och även Runar Nordgen. ${ }^{4}$ Systrarna reste tillsammans över Atlanten och under tiden i USA tillbringade de en stor del av fritiden tillsammans. Därför förekommer Aili och Runar flera gånger i Sally Salminens självbiografi över tiden i USA, boken Min amerikanska saga. ${ }^{5}$ Ailis och Runars historia tangeras också i Aleksi Huhtas och Mats Wickströms tillsvidare opublicerade uppsats om Ailis och Runars vänner Aili och Georg Backlund. ${ }^{6}$

För att granska de resor paret Nordgren gjorde på flera plan, tar vi i denna artikel avstamp i den biografiska metoden. Enligt historikern Christina Florin kan man se människan som en mötesplats för olika processer: sociala, politiska, kulturella och historiska. Genom att studera en individ under olika tider, i olika sociala rum, på olika platser och i samband med olika händelser kan man se hur dessa format honom eller henne. Livsberättelser ger också många tillfällen att reflektera kring kön, klass, etnicitet och sexualitet samt diskutera

3. Runar Nordgren nämns i ett citat i Mats Wickströms och Jonas Ahlskogs artikel "Socialt och kulturellt medvetna medborgare. Socialistisk finlandssvensk folkbildning från samarbete till splittring i Folkets Bildningsförbund r.f. 1945-49", Historisk Tidskrift för Finland 102, 2017:2, s. 279.

4. Ulrika Gustafsson, Min ljusa stad. Sally Salminen, livet och litteraturen, SLS Varia 3, Helsingfors: Svenska litteratursällskapet i Finland \& Stockholm: Appell förlag 2019.

5. Sally Salminen, Min amerikanska saga, Helsingfors: Schildts i968.

6. Aleksi Huhta \& Mats Wickström,"Rakkautta ja radikalismia New Yorkissa: Kahden nuoren suomenruotsalaisen siirtolaismatka kommunismiin", Miika Tervonen \& Johanna Leinonen (toim.), Vähemmistöt muuttajina, Turku: Siirtolaisuusinstituutti [under utgivning]. 
existentiella frågor såsom tidsandan, mentaliteten och känslor både som psykologiska och sociala fenomen. ${ }^{7}$ För att en person skall vara historiskt intressant behöver hen varken vara en känd eller genomsnittlig person i sin samtid. Genom att granska de ovanliga och dem som tillhör en minoritet, i detta fall Aili och Runar som var både finlandssvenskar och kommunister, kan man visa på de möjligheter till tanke och handling en individ har haft under en viss tid på en bestämd plats. ${ }^{8}$ Enligt Ann-Catrin Östman och Lena Marander-Eklund kan biografiska berättelser ha en normativ kraft. Berättandet skapar således en självrepresentation. ${ }^{9}$ Det samma kan sägas gälla för brev, där skribenten inte nödvändigtvis beskriver skeenden sanningsenligt, utan försöker sortera sina tankar och skapa en sammanhängande, förståelig berättelse. ${ }^{10}$

Vårt material består av en rik blandning av olika källor, som sammantaget möjliggör såväl en bred översikt över Ailis och Runars liv som fördjupningar i deras tanke- och känsloliv. Den källa som mest knyter an till tanken om självrepresentation är Runar Nordgrens dagbok från början av 1930-talet. Dagboken innehåller trots namnet inte enbart nedteckningar av händelser från dag till dag. I dagboken skriver Runar även om sin uppväxt och sitt tänkande överlag och en del avsnitt är skrivna i form av brev till frun Aili. I dag bevaras dagboken på Folkets Arkiv i Helsingfors och är fritt tillgänglig för forskning. I Folkets Arkiv finns även Finlands kommunistiska partis kadersektions personfiler över Aili och Runar. Tidnings- och tidskriftsmaterial om och av Aili och Runar är en viktig källa. En radiointervju med Aili

7. Christina Florin, "Biografia rajoja rikkomassa. Kolme esimerkkiä ruotsalaisesta elämänkertatutkimuksesta”, Heini Hakosalo, Seija Jalagin, Marianne Junila \& Heidi Kurvinen (toim.), Historiallinen elämä. Biografia ja historiantutkimus, Historiallinen Arkisto I4I, Helsinki: Suomalaisen Kirjallisuuden Seura 20I4, s. 43.

8. Heini Hakosalo, Seija Jalagin, Marianne Junila \& Heidi Kurvinen, "Yksilöiden vetovoima", Historiallinen Aikakauskirja 2012:4, s. 376.

9. Lena Marander-Eklund \&Ann-Catrin Östman,"Biografiska betydelser - norm och erfarenhet i levnadsberättelser”, Lena Marander-Eklund \& Ann-Catrin Östman (red.), Biografiska betydelser - norm och erfarenhet i levnadsberättelser, Hedemora: Gidlunds förlag 2oIr, s. 7-8.

Io. Anu Lahtinen, Maarit Leskelä-Kärki, Kirsi Vainio-Korhonen \& Kaisa Vehkalahti, "Kirjeiden uusi tuleminen", Anu Lahtinen, Maarit Leskelä-Kärki, Kirsi VainioKorhonen \& Kaisa Vehkalahti (toim.), Kirjeet ja historiantutkimus, Helsinki: Suomalaisen Kirjallisuuden Seura 20II, s. 2I-22. 
Nordgren gjord år 1987 utgör likaså en värdefull källa. Såväl ämnets som källornas natur har gett anledning till en del etiska överväganden. Att vi ändå valt att skriva denna artikel utgående från det personliga materialet hänger samman med vår önskan att beskriva Runars och Ailis livsöden så mångsidigt och flerstämmigt som möjligt. Såsom Kirsi Vainio-Korhonen påpekat, hjälper detta angreppssätt dagens läsare att bättre förstå de undersökta personernas val. ${ }^{11}$

\section{Från Yttermark till New York}

Runar Evald Nordgren föddes den 27 september I9II i byn Yttermark i Närpes kommun i Sydösterbotten. Han var bönderna Adrian och Anna Christina (Anna Stina) Nordgrens elfte och sista barn. Två av barnen avled tidigt. Adrian Nordgren dog i en olycka den 27 april I9I4 då Runar var blott två år gammal. ${ }^{12}$ "En svår tid uppstod $\mathrm{i}$ hemmet när pappa dog" skrev Runar i sin dagbok i New York 17 år senare när han reflekterade över sin barndom. Världskriget och den därpå följande recessionen gjorde enligt Runar ont värre och hans mor tvingades sälja hälften av familjens hemman på 45 tunnland, vilket dock inte hjälpte familjen ur dess ekonomiska trångmål: "Efter mina syskon blevo fullväxta flydde de hemmet och tog sig ut i världen för att skapa sig en lyckligare framtid än vad hemmet bjöd på." Till slut var endast Runar och hans bror Gunnar kvar med mor Anna Stina. Gården var för liten för två bröders utkomst, "varför frågan blev att en måste resa bort". Runar förklarade att valet föll på honom eftersom han hade en "livssyn som gav mig stort hopp om framtiden". Att framtiden fanns i Amerika framstod också som klart. ${ }^{13}$ Innan Runar begav sig iväg till framtidslandet på andra sidan Atlanten gick han dock ut folkskolan i Närpes.

II. Kirsi Vainio-Korhonen, "Vastuullinen historia", Satu Lidman, Anu Koskivirta \& Jari Eilola (toim.), Historiantutkimuksen etiikka, Helsinki: Gaudeamus 20I7, s. $42-44$.

I2. "Runar Evald Nordgren", Samlingspärm för Runar Nordgren, Kadersektionens samling, Folkets Arkiv (FA), Helsingfors.

I3. Runar Nordgrens dagbok, odaterat inlägg, Runar Nordgrens manuskript, 6665:I7, Aili och Runar Nordgrens arkiv, FA. 
På skolavslutningen den 4 maj 1929 var det Runar som framförde elevernas tack till lärarna. Festen inleddes med bön och tal av skolans religionslärare, pastor Edvin Stenwall. Stenwall var en förgrundsgestalt i den finlandssvenska fredsrörelsen. Han hade år 1926 grundat tidskriften Frid på jorden: organ för fred och kristet sambällsliv, som utgavs i Närpes med Stenwall som redaktör och ansvarig utgivare. År 1929 grundade Stenwall föreningen Närpes fredsvänner och Runar tog del i verksamheten. ${ }^{14}$ Stenwall var övertygad om "det berättigade i arbetarrörelsens program" ${ }^{15}$ och den pacifistiska och progressiva kristendom som Stenwall representerade var en inkörsport till socialistiskt tänkande för många österbottningar. ${ }^{16}$

Efter avslutad skolgång var Runar enligt sina egna dagboksord"färdig för livets hårda kamp” och begav sig likt många andra Närpesbor iväg mot Amerika. Den tidigare så gott som öppna porten till Förenta staterna hade dock stängts i och med de strikta invandringslagar som infördes i början av 1920-talet. Migranterna sökte sig i stället till Kanada där gränserna fortfarande var öppnare för finländare. Efter två veckor i den kanadensiska staden Hamilton i närheten av Niagarafallen och den amerikanska gränsen var Runar och en grupp kamrater redo att "rymma över till U.S.A.”. I sin dagbok beskrev Runar senare gränsöverskridningen på följande sätt:

Natten låg mörk och dånet från världens största vattenfall trängde sig som åskan i den stilla natten. Spänningen var stor och många tankar tumlade om varandra i mitt huvud. Försöket att komma över var på den tid riskabelt, och fängelse hålorna lurade gapande mot oss. Men lyckan som vi ej kände stod oss bi, och lördags morgon när solen sugit daggen från marken var vi över på U.S.A. sidan. ${ }^{17}$

\footnotetext{
I4. "Runar Nordgren - jordbrukets, industrins, kooperationens man, en god österbottning", Ny Tid 25/2 I954.

15. Edvin Stenwall,"Vid skiljovägen”, Frid på jorden: organ för fred och kristet sambällsliv I929:3, s. 2I.

16. Dennis Rundt, Munsalaradikalismen: en studie i politisk mobilisering och etablering, Åbo: Åbo Akademis förlag 1992.

I7. Runar Nordgrens dagbok, odaterat inlägg.
} 
Runar och de övriga österbottningar han korsat gräsen med hösten I929 sällade sig till de omkring 400 ooo illegala immigranter som befann sig i Förenta staterna vid slutet av I920-talet. ${ }^{18}$ Runar tog sig vidare till New York, där hans två bröder Magnus och Thure Nordgren bodde, och "börsspekulanterna kastade sig från skyskraporna", som Runar uttryckte det i en folkdemokratisk jultidning år 1947. ${ }^{19}$ En tid därefter anlände Aili och Sally Salminen, två systrar från Vårdö på Åland, lagligt till USA. Systrarna hade köpt biljetter i första klass, enligt Sally för att undvika komplikationer under överfarten. De stötte inte heller på problem och i mars 1930 steg de i land i New York. ${ }^{20}$

\section{Från butiksbiträde i Saltvik till hembiträde på Manhattan}

Aili Amanda Henriette Salminen föddes den 22 oktober I908 i Vårdö som det nionde barnet till småbrukarna Erika och Hindrik Salminen. Ailis far Hindrik försörjde sin stora familj bland annat genom att handha postgången från familjens hemby Vargata till Fasta Åland. Han åkte också över till Amerika ett antal gånger för att arbeta under den fria invandringens tid. När Aili var fem år gammal drunknade hennes postförande far i Båthusviken på Vårdö. Den familj med tio barn han lämnade efter sig blev fattig. ${ }^{21}$ Enligt Aili rådde det dock"en efter förhållandena intressant atmosfär" $i$ det läsande hem hennes mor Erika skötte med god hjälp av äldste sonen Albin, som övertog faderns roll som försörjare. Det var också Albin som lärde Aili och hennes minst lika läshungriga och förtrogna storasyster Sally (f. I9o6) att läsa de böcker han hämtade hem. Albin uppmanade även sina systrar att vara samhällskritiska och självständiga. ${ }^{22} \mathrm{I}$ en radiointervju gjord år I987 beskriver Aili hur hon både såg och upplevde stora klasskillnader

18. Jane Perry Clark, Deportation of Aliens from the United States to Europe, New York: Arno Press i969, s. 253.

I9. Runar Nordgren, "Bland arbetslösa finlandssvenskar i Amerika”, Folkets jul I947, s. Io.

20. Aili Nordgren,"Min vän Sally", Anna Bondestam (red.), Sallys saga. En minnesbok om Sally Salminen, Helsingfors: Schildts I986, s. 77; Salminen, Min amerikanska saga, s. I4.

21. Gustafsson, Min ljusa stad, s. I6-I7.

22. Aili Nordgren, "Min syster Sally", s. 73 . 
under uppväxten på Åland och att dessa orättvisor senare bidrog till att hon engagerade sig $\mathrm{i}$ arbetarrörelsen. ${ }^{23}$

Den 23 augusti I9I8 skrevs Aili in i Vårdö högre folkskola och erhöll avgångsbetyg från samma skola den 24 maj I92I. Ailis betyg var i huvudsak goda, det vill säga tio eller nio, och i uppförande samt ordning och uppmärksamhet bedömdes hon med högsta betyg. ${ }^{24}$ Därefter kom "de långa tomma åren utan skola” som Aili långt senare uttryckte det i den nämnda radiointervjun. Ett stipendium på 500 mark från Vårdö ungdomsförening, där Aili var väldigt aktiv, för att gå i Ålands folkhögskola "räddade" den I7-åriga Aili: ”Jag var så glad när jag fick komma till Folkhögskolan. Jag började leva på nytt." Där skrev hon uppsatser som hon fick mycket beröm för av sin lärare $\mathrm{i}$ litteratur Jan Sundberg, som enligt Aili var underbar och älskad av alla. Enligt Aili lärde Sundberg henne att skriva och att värdesätta "riktig litteratur". ${ }^{25}$

När Runar Nordgren reste till Förenta staterna hösten I929 arbetade Aili som butiksbiträde vid Saltviks Andelshandel, vilket hon gjort sedan början av år 1928. ${ }^{26}$ Efter näringsfrihetslagens instiftande år I879 grundades nya butiker också utanför städernas centrum. Detta innebar inte bara ett ökat utbud och lättare tillgång till varor utan även arbetstillfällen för ortens ungdomar. Flera av syskonen Salminen försörjde sig åtminstone tidvis genom att arbeta som butiksbiträden. ${ }^{27}$

Enligt Sally Salminens levnadstecknare Ulrika Gustafsson var det Sallys syster Aili som var pådrivande i systrarnas beslut att flytta till Förenta staterna. ${ }^{28}$ Ailis iver berodde enligt Sally på att Ailis pojkvän begett sig till Amerika, men då systrarna skulle resa hade Aili redan "funnit en annan vän och for därför sörjande sin väg". ${ }^{29}$ När Aili själv blickade tillbaka på sitt liv angav hon den hårda uppväxten och en

23. Arkivpärlan: Aili Nordgren, Ålands Radio, https://alandsradio.ax/arkivparlan/ arkivparlan-aili-nordgren (hämtad 4/32020).

24. Aili Nordgrens avgångsbetyg från högre folkskolan i Vårdö, Aili Nordgrens handlingar, 6665:25, Aili och Runar Nordgrens arkiv, FA.

25. Arkivpärlan: Aili Nordgren.

26. "Handelslagens personal", Handelslaget I928:I, s. II.

27. Aulis Alanen, Suomen maakaupan historia, Jyväskylä: Kauppiaitten kustannus Oy I957, s. 56r; Nordgren, "Min syster Sally", s. 75.

28. Gustafsson, Min ljusa stad, s. 39.

29. Salminen, Min amerikanska saga, s. 32. 
längtan efter något mera som motiv till att syskonen gav sig ut i världen för att skaffa sig det de önskade och utvecklas som människor. ${ }^{30}$ Till skillnad från Runar och de övriga österbottningarna i hans sällskap som tog sig in i USA illegalt, skaffade sig Aili och Sally visum på amerikanska konsulatet i Helsingfors i november i929. I början av mars 1930 påbörjades båtresan till Amerika i Göteborg och den I8 mars 1930 anlände systrarna Salminen med det transatlantiska passagerarfartyget S/S Drottningholm till New York.

Trots den stora depressionen fanns det en efterfrågan på unga kvinnliga hembiträden av nordisk härkomst bland societeten i staden, och blott en vecka efter att de stigit i land hade såväl Sally som Aili erhållit anställningar. ${ }^{31}$ Systrarnas arbetsplatser låg ofta nära varandra, och medan Sally arbetade för olika medelklassfamiljer och ofta bytte arbetsplats, arbetade Aili under sina fyra år i New York i tre överklasshem på Fifth Avenue och Madison Avenue. Aili jobbade bland annat för bankiren Floyd G. Blair, vice president för City Bank of New York, i dag Citibank. ${ }^{32}$ City Bank of New York var en av USA:s största banker och även väletablerad internationellt. Efter Wall Street-kraschen hösten I929 utpekades bankens verkställande direktör Charles Mitchell som en av de skyldiga till börsens kollaps. ${ }^{33}$ Ailis arbetsgivare var alltså i allra högsta grad en man i den krisande världskapitalismens centrum. Det var dock inte i första hand arbetet hos bankmannen Blair eller de övriga miljonärerna på Upper East Side på Manhattan som radikaliserade Aili, utan Runar och hans kamrater i Finländska Ungdomsföreningen.

\section{Aili och Runar i RÖD LUST Och NÖD}

Enligt Aili kom hon själv in i arbetarrörelsen "genom Runar". ${ }^{44}$ Sally mindes att systerns pojkvän Runar vid den här tiden var en "storvuxen

30. Arkivpärlan: Aili Nordgren.

31. Gustafsson, Min ljusa stad, s. 39-40.

32. Nordgren,"Min syster Sally", s. 82;"Floyd G. Blair, Banker, Dies; Led Philharmonic Society Here; Ex.Executive of National City Was Lawyer and Adviser to Mellon on War Debts", New York Times 30/ro I965.

33. Floyd Norris, "Looking Back at the Crash of '29", New York Times I7/Io I999.

34. Arkivpärlan: Aili Nordgren. 
kraftig pojke med gult hår [---] med en god blick och tro på idealen skriven i hela det ännu barnsliga runda ansiktet". ${ }^{35}$ I radiointervjun långt senare konstaterar Aili att parets första möte gick till precis så som hon beskrivit det i sin roman Innan dagen börjar. ${ }^{36}$ Skildringen av dansen i migrantromanen från år 1946 ger en intim inblick i de sammanhang och sinnesstämningar som Aili och Runar rörde sig $i$ då de möttes:

Eva dansade.

Mjukt och lätt dansade hon, med huvudet tillbakakastat och ett varmt leende på de röda läpparna. Omkring henne dansade de alla. Finnar, svenskar, ålänningar, österbottningar och emigranter från främmande länder.

Har du arbete?

Nej - vi är utan, vi är alla utan.

Har du arbete?

$\mathrm{Ja}$ - vi arbetar sexton timmar om dagen. Ja, vi är trötta av arbete.

Men nu dansar vi. Vi dansar alla, arbetslösa och arbetande, trötta och bekymrade, leende och lyckliga, alla dansar vi på finnhallen i Harlem. Det är varmt omkring oss. Svetten rinner och flickornas klänningar är våta på ryggen, männens skjortor klibbar vid kroppen, men dansen går. ${ }^{37}$

Aili och Runar började sällskapa och snart drogs hon med i Runars socialistiska sfär, vilket hon beskriver i radiointervjun från I987:

Han var då med i en finlandssvensk förening [...] som egentligen var en socialistisk ungdomsförening och han var då redan övertygad socialist, kommunist kan man säga, vi blev förälskade och han fick mig med i den här föreningen och Sally kom också med naturligtvis när jag kom. Och på det sättet vaknade jag då upp från den tillvaro jag varit placerad i genom mitt arbete för miljonärerna och jag började se och förstå livet på ett annat sätt. Jag blev kommunist [...] vi var verkligen glödande kommunister. ${ }^{38}$

35. Salminen, Min amerikanska saga, s. 51.

36. Arkivpärlan: Aili Nordgren.

37. Aili Nordgren, Innan dagen börjar, Helsingfors: Schildts I946, s. I3.

38. Arkivpärlan: Aili Nordgren. 
Hösten 1929 hade en grupp finlandssvenska ungdomar i USA grundat Finländska ungdomsföreningen (FUF). Föreningen tog modell för sin organisation från de österbottniska ungdomsföreningar dess medlemmar var välbekanta med, men var från första början mer politiserad än sina förebilder ${ }^{39} \mathrm{FUF}$ hade tät kontakt till det kommunistiska partiet i USA och framför allt dess skandinaviska underavdelning, Skandinaviska Arbetarförbundet i Amerika (SAFA). De mest aktiva lokalorganisationerna fanns i Chicago och i regionen New England. I New York hade föreningen år 1929 endast $8 \mathrm{I}$ medlemmar. De svenskspråkiga kommunisterna i New York hade en mycket mindre verksamhet än den finskspråkiga Yhdysvaltain Suomalainen Työväenjärjestö (STJ), som år 1932 hade sammanlagt 9232 medlemmar. För de finlandssvenska radikalerna från Österbottens så gott som enspråkigt svenska kommuner var det dock mer praktiskt och sannolikt också mer etniskt osökt att i första hand verka i de svenskspråkiga sammanhangen än att söka sig till de finskspråkiga kommunisterna i Harlem. FUF upprätthöll dock kontakt med de finskspråkiga landsmännen och kamraterna och föreningen var mån om att framhäva sin finländskhet inför svenskarna. De finlandssvenska ungdomarna i New York skapade således ett eget radikalt rum mellan svenskarna och finnarna. Hösten 1930 började FUF ge ut en månadstidning kallad Gnistan (efter de ryska marxisternas första tidning Iskra). Aili och Runar deltog i arbetet med tidningen tillsammans med bland andra Georg Backlund och Aili Holm, ett radikalt rött par vars historia delvis är sammanflätad och delvis parallell med paret Nordgrens. ${ }^{40}$

Aili och Runar gifter sig den I8 januari 1931. Runar var då 20 år gammal och Aili ett par år äldre. I sin dagbok beskriver Runar tiden efter bröllopet i positiva ordalag, han hade "ett glatt liv" med sin älskade hustru. Aili jobbade dock mycket så de kunde inte träffas varje dag, men de talades vid i telefon och Runar tog ut Aili om söndagseftermiddagarna för att se sig omkring i staden. Ibland gick de på bio. ${ }^{41}$ Vid sidan om att läsa tidningar och lyssna på radio hörde biobesök till de mest populära nöjena i I930-talets USA, trots den

39. Huhta \& Wickström, "Rakkautta ja radikalismia New Yorkissa".

40. Ibid.

4I. Runar Nordgrens dagbok, passim. 
ekonomiska krisen. Ett biobesök var billigt och när man väl betalat inträdet kunde man stanna kvar så länge man ville. Förutom filmföreställningar ordnades även olika typer av shower på biograferna. ${ }^{42}$ Aili själv har beskrivit sig som en "utåtriktad människa" i New York, en person som ägnade sig åt "sång, dans, politik och kärlek". ${ }^{43}$ Hon hade lätt att få arbete och även om arbetet som hembiträde inte var välbetalt blev det ändå en del pengar över.

Förutom umgänge med likasinnade ungdomar och biobesök var ett fritidsnöje för systrarna Salminen att uppleva det framväxande konsumtionssamhället i USA. Under sina lediga stunder vandrade de omkring i New York och beundrade skyltfönstren med vackra kläder, böcker och andra handelsvaror. Då systrarna köpt något nytt, packade de ihop sina avlagda kläder och skickade hem dessa till släktingarna på Åland. Även i övrigt stod systrarna Salminen i ständig kontakt med familjen på Åland. I sina brev skrev de om livet i USA och om de tankar som umgänget med kommunisterna i New York hade väckt. Till familjen hörde också systern Rauha Åkerblom, vars man Valdemar redan tidigt sympatiserat med kommunismen. $\mathrm{Nu}$ fick han medhåll av Aili och Sally i USA. ${ }^{44}$

Även om Runar var lycklig över äktenskapet med Aili, grusades snart de förhoppningar han sedan barndomen haft på Amerika. I sin dagbok utrycker han upprepade gånger besvikelse över att livet i USA inte blev som han tänkt sig. Hans intryck av New York var negativt, han fann staden smutsig och ohygienisk, en plats där arbetarna tvingades bo i fängelselika kvarter. Varken han eller kamraterna lyckades få något annat än tillfälliga inhopp på diverse arbetsplatser på grund av den ekonomiska depressionen. Runar arbetade bland annat som målare och under en längre period var han anställd av en fabrik som tillverkade timmermansverktyg. På fabriken, som hade omkring etthundra anställda, fick han omsätta sina tankar kring arbetarnas rättigheter i praktiken och vid ett tillfälle fungera som strejkorganisatör. ${ }^{45} \mathrm{De}$ långa perioderna av arbetslöshet gjorde dock att han ständigt drogs med ekonomiska bekymmer.

42. Huhta \& Wickström, "Rakkautta ja radikalismia New Yorkissa".

43. Aili Nordgren, "Min vän Sally", s. 74 .

44. Salminen, Min amerikanska saga, $\mathrm{s.} 44,49$.

45. "Runar Nordgren", Ny Tid 25/2 1954. 
Då förväntningarna på det nya livet i USA smulades sönder, vände många av de finländska arbetarna i Amerika blicken mot Sovjetunionen. Runar skrev i sin dagbok om hur han och hans kamrater tänkte kring denna möjlighet:

Vi äro fem kamrater från Finland som går ifrån "de stora möjligheternas land" Amerika. Från min hemsoken [sic] är kamraterna Georg Backlund och Walfrid Anderson. Från Sideby kamrat G-t Grönmark och från Jeppo kamrat Gunnar Ström. Vi äro den första gruppen av finlandssvenskar som ger sig till Sovjet för att pröva möjligheterna att få en finlandssvensk koloni till stånd. Detta är vårt hopp, vår framtids drömmar. ${ }^{46}$

Enligt Sally Salminen var det inte heller enbart kärlek som föranledde det unga parets giftermål. Drömmen om arbetarparadiset öster om Finland präglade bröllopsfesten i bröderna Nordgrens lägenhet:

Vi pratade mycket. Och drack kaffe. Och pratade igen. Ämnet för vårt prat var framför allt den förestående resan. Det var den mer än giftermålet som var före, ty vi hade ju alla vetat att Aili och Runar "skulle ha varandra". Men resan - ja, det var just den som skyndat på vigseln inför New Yorks borgmästare. Runar och en österbottnisk kamrat, han hette Georg Backlund, skulle lämna utvandrarnas stora gamla mål för att utvandra på ett annat sätt. De ämnade resa till Sovjetunionen. Så fulla av tillit var de till det som utmålats för dem i deras egen propagandalitteratur. Och så stor var deras besvikelse på depressionens USA. De hjälptes beredvilligt i väg av syskon och vänner. ${ }^{47}$

Enligt Runars dagboksanteckningar var Aili glad över att han skulle lämna USA, också då det började dra ihop sig till avfärd och han själv blev allt mer tveksam. Utmaningarna var många. Runar var svartsjuk, rädd att Aili skulle träffa en ny man efter att han gett sig av. Hans brist på pengar tvingade honom att välja mellan att köpa nya kläder inför resan eller att spara fickpengar till överfarten. Dessutom var

46. Runar Nordgrens dagbok, odaterat inlägg.

47. Salminen, Min amerikanska saga, s. II6. 
Runar rädd för att hamna ur askan i elden, och inte få ett arbete då han kom fram. Om det skulle gå så illa i Sovjetstaten återstod endast ett alternativ, att återvända hem till Finland. Att resa till Finland skulle dock innebära militärtjänstgöring, något som Runar fruktade. ${ }^{48}$ Enligt historikern Anders Ahlbäck fanns det en utbredd rädsla för militärtjänstgöringen i Finland under 1920-talet, en rädsla som späddes på av tidningsrapporter om undermåliga förläggningar, usel tillgång till hälsovård och trakasserier från överordnade. ${ }^{49}$ Trots sitt tvivel höll Runar dock fast vid beslutet att lämna USA: "Men det kan ej hjälpas, jag kan ej heller lämna här, ty fattigdomen tränger sig allt närmare på mig. Vår enda räddning är att resa till det land där socialismen uppbygges. Vår framtid - vår lycka." ${ }^{50}$

Före avfärden ordnades en avskedsfest för dem av resenärerna som var aktiva i FUF. Vid denna fest hölls tal av bland andra Runars reskamrat Georg Backlund och Runar själv. I sitt tal uppmanade Runar FUF att fortsätta kampen i New York med socialistiska slagord: "Upp till kamp emot kvalen. Vi har ingenting att förlora men en värld att vinna." Kvällsfesten avslutades med kaffeservering och Internationalen. Resenärerna fick också en gåva att ta med sig på resan, FUF:s flagga, vilken de vid ankomsten skulle överräcka till arbetarna i Sovjetunionen. ${ }^{51}$ Tidigt våren 1932 inleder de fem kamraterna resan över Atlanten. På basis av Runars dagbok verkar han ha varit sjösjuk och full av tvivel under resan ombord på det norsk-danska fartyget Frederik VIII med destination Köpenhamn, ett fartyg som han beskriver som "en kobåt som transporterar arbetare". ${ }^{52}$

Medan Runar åkte till Sovjet, stannade Aili kvar i USA. I Runars dagbok får man bilden att Aili tog den förestående tillfälliga skilsmässan med jämnmod, vilket motsägs av Sallys beskrivning av tiden efter Runars avfärd. Enligt henne var Aili mycket orolig för hur det skulle gå för Runar. ${ }^{53}$ Samtidigt såg Aili sig nödgad att stanna kvar i New

\footnotetext{
48. Runar Nordgrens dagbok, passim.

49. Anders Ahlbäck, Soldiering and the Making of Finnish Manhood. Conscription and Masculinity in Interwar Finland, 1918-1939, Åbo: Åbo Akademis förlag 2010, s. 87.

50. Runar Nordgrens dagbok, 24/I 1932.

51. Huhta \& Wickström, "Rakkautta ja radikalismia New Yorkissa".

52. Runar Nordgrens dagbok, I9/2 1932.

53. Salminen, Min amerikanska saga, s. II8.
} 
York för att tjäna pengar till sin egen hemresa. Dessutom måste hon arbeta för att kunna hjälpa Runar att betala av en skuld på 200 dollar som han hade dragit på sig. Runar skriver i sin dagbok att de kommer att vara åtskilda i sju månader på grund av hans skulder, men att han är så glad att Aili vill arbeta för att kvittera hans lån. ${ }^{54} \mathrm{Vi}$ vet inte exakt hur mycket Aili tjänade, men för tjänstefolk som bodde hemma hos sina arbetsgivare, såsom Aili gjorde, var den genomsnittliga lönen 40 dollar i månaden. Sallys första lön var 50 dollar. ${ }^{55}$

\section{Från Sovjet och Upper East Side till skydds- KÅSFESTER I KARELEN}

Runar gjorde ett litet uppehåll i dagboken under resan över Atlanten och därför vet vi inte exakt hur resan gick till. Den följande anteckningen handlar nämligen om hur det lilla österbottniska ressällskapet korsat gränsen mellan Lettland och Sovjetunionen, där de fått sina pass och sitt bagage noggrant granskade, samt satt sig på det skakande tåget mot Moskva. Nu var deras drömmars mål nära! Men som flera andra av de amerikafinländare som lämnade USA för ett liv i Sovjetunionen kom Runar och hans vänner att bli besvikna över det elände och den nöd de såg. Runar stod i ständig brevkontakt med Aili och hon blev snart varse det trångmål som resenärerna befann sig i. Problemen höll henne vaken om natten. ${ }^{56}$ Resan till Moskva hade gått via Köpenhamn, Danzig och Riga. Från Moskva fortsatte Runar och Georg Backlund till Leningrad. Genom tågfönstret såg kamraterna att drömmen om en industriell och modern arbetarstat ännu inte hade besannats. Väl framme i Leningrad hade kamraterna svårt att hitta bostad. Situationen fick en tillfällig lösning då de erbjöds sovplats på golvet hos några finländare som de råkade på, men någon långsiktig lösning på bostadsbristen hittade de inte. Utan bostad och med bristfälliga språkkunskaper såg läget verkligen mörkt ut. Runar Nordgren konstaterade snabbt att det inte fanns något som ingav honom "trust", det vill säga tro på att han och Aili skulle kunna

54. Runar Nordgrens dagbok 26/I 1932.

55. Handbook of Labor Statistics 1936 Edition, Washington: United States Department of Labor 1936, s. IIo5; Salminen, Min amerikanska saga, s. 33.

56. Salminen, Min amerikanska saga, s. II7. 
etablera sig i Sovjetunionen. De ekonomiska bekymren lättade inte och han var fortfarande beroende av ekonomiskt stöd från Aili. Utan arbete i Leningrad"så är jag tvungen att resa över till Finland, dit jag aldrig vill gå" skrev Runar i sin dagbok. Han konstaterar också att han aldrig hade lämnat New York om han vetat hur det skulle bli. ${ }^{57}$

Trots att Runar bestämt sig för att inte återvända till Finland blev situationen snart sådan att det inte återstod några andra alternativ. Georg och han satte sig återigen på tåget. Med sig i bagaget hade de Lenins samlade verk, en samling böcker som de fruktade skulle bli beslagtagna vid gränsen. De hade dock tur och ingen granskning genomfördes, i stället fortsatte tåget raka vägen över gränsen till Riihimäki. ${ }^{58}$ Efter hemkomsten till Närpes den 20 mars 1932 skrev Runar i sin dagbok till Aili på andra sidan Atlanten: ”Jag är trött, riktigt trött, så jag kan inte skriva någott [sic]. Endast det, jag är hem, jag är hem - min Aili, det är så konstigt allt här i livet ..." ${ }^{\prime 9}$

Här slutar Runars dagbok och det är svårt för oss att utgående från det material vi har bedöma hur Runar och Aili uppfattade Sovjetresans snöpliga slut. Med tanke på det vi vet om deras förhoppningar före resan till Sovjetunionen och Runars rädsla för att återvända till Finland är det ändå klart att drömmen om ett bättre liv i Sovjetunionen hade gått i kras och att framtiden såg oviss ut. De övergav dock inte sin ideologi. Sally Salminen skriver att "varken besvikna förhoppningar eller beslutet att vända bolsjevikstaten ryggen hade ändrat det unga paret Nordgren i deras politiska åskådning”. ${ }^{60}$ Misslyckandet med att upprätta en "finlandssvensk koloni” i Sovjetunionen var säkert tungt att bära med tanke på de förhoppningar som projicerats på arbetarnas paradis. Samtidigt besparades Runar och Aili och deras FUF-kamrater sannolikt från de utrensningar och avrättningar som flertalet av finländarna i Sovjetunionen drabbades av på ett eller annat sätt under Stalins stora terror mot slutet av 1930-talet. ${ }^{61}$

57. Runar Nordgrens dagbok, I/3 1932. Likt sin reskamrat Runar var Georg Backlund besviken på vad han mötte i den stat bolsjevikerna byggt upp, se Huhta \& Wickström,"Rakkautta ja radikalismia New Yorkissa".

58. Huhta \& Wickström, "Rakkautta ja radikalismia New Yorkissa".

59. Runar Nordgrens dagbok, 20/3 1932.

6o. Salminen, Min amerikanska saga, s. II9.

6I. Markku Kangaspuro, Neuvosto-Karjalan taistelu itsehallinnosta. Nationalismi ja suomalaiset punaiset Neuvostoliiton vallankäytössä 1920-1939, Helsinki: Suomalai- 
Väl tillbaka i Finland måste Runar bestämma sig för vad han skulle göra i framtiden. Aili befann sig långt ifrån Närpes och kunde inte aktivt påverka besluten, även om Runars bryderi och parets framtid upptog mycket av hennes tankar. I New York diskuterade Aili och Sally för- och nackdelar med olika framtidsplaner. Systrarnas arbetsplatser låg vid den här tidpunkten nära varandra vilket gjorde att de kunde ses oftare än tidigare och smidigt bege sig ut i stadens vimmel tillsammans då de slutat för dagen. Sommaren 1932 hann de också med en dagsutflykt med båt till kuststaden New Rochelle, vilket påminde dem båda om livet hemma på Åland. Men till och med denna glada utflyktsdag var Aili enligt systern Sally nedstämd eftersom hon saknade sin Runar. ${ }^{62}$

Efter en tid på hemgården i Närpes bestämde sig Runar för att utbilda sig till agrolog vid Högre lantbruksläroverket i Åbo. Han hade dock inte de betyg som krävdes, men kunde utnyttja det faktum att han hade vuxit upp på ett jordbruk och använde det praktiska arbetet på hemgården för att möta inträdeskraven. När uppbådsnämnden i Vasa i september 1932 dessutom beslöt att placera honom i lantvärnet (ersättande reserven) i stället för att beordra honom till militärtjänstgöring var studievägen öppen. ${ }^{63}$ År 1932, det år Runar Nordgren skrevs in i matrikeln, verkade Högre lantbruksläroverket i Åbo på Klostergatan I5. Nytt för året var att antalet undervisningstimmar hade minskats kraftigt och terminen förlängts, vilket gjorde det möjligt att avlägga studierna på endast två år, i kombination med därpå följande praktik. Orsaken till nedskärningen var ekonomisk; från skolans håll ville man skära ner på utgifterna men också göra det billigare att erhålla en examen. Med tanke på det ekonomiska trångmål Runar befann sig i var detta sannolikt en välkommen reform.

Under studierna, som enligt Sally Salminen bekostades med hustrun Ailis pengaförsändelser från New York, avlade Runar en mellan-

sen Kirjallisuuden Seura 200o; Eila Lahti-Argutina, Olimme joukko vieras vaan. Venäjänsuomalaiset vainoubrit Neuvostoliitossa I930-luvun alusta I950-luvun alkuun, Turku: Siirtolaisuusinstituutti 20or; Ossi Kamppinen, Palkkana pelko ja kuolemaNeuvosto-Karjalan suomalaiset rakentajat, Jyväskylä: Docendo 2019.

62. Salminen, Min amerikanska saga, s. II8, I25.

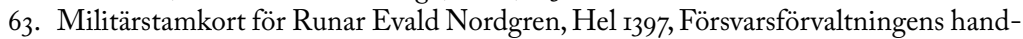
lingar, Riksarkivet, Helsingfors. 
praktik hemma i Österbotten vid Yttermark och Pörtom andelsmejeri. Efter examination år I934 återstod då den så kallade efterpraktiken. För att avlägga praktiken reste Runar till Leitimo herrgård i Viborgs landskommun, och han gjorde resan tillsammans med Aili. ${ }^{64}$ Aili återvände från USA år I934 och återförenades med sin man på Karelska näset, där hon lärde känna de karelska statare hon senare skrev om i sin debutroman Mörk längtan (1943). Vistelsen i Karelen var enligt Aili svår på flera sätt och omgärdad av strikta regler. Makarna Nordgren fick instruktioner om att undvika kontakt med arbetarna och var påbjudna att delta i skyddskårens fester. Festerna var enligt Aili "fruktansvärda, det var så mycket rysshat". ${ }^{65}$ Den plats där herrgården en gång stod finns numera i Ryssland. ${ }^{66}$

\section{Arbetarrörelseaktivism i Österbotten}

Efter erfarenheterna i Karelen ville Runar inte arbeta på en herrgård utan började se sig om efter andra försörjningsmöjligheter. ${ }^{67}$ År I935 föddes Ailis och Runars första barn, dottern Christina. Följande år flyttade familjen Nordgren tillbaka till Österbotten. Denna gång till Vasa där de, tillsammans med vännerna Georg och Aili Backlund, började arbeta inom arbetarrörelsen i svenska Österbotten. Efter stiftandet av de så kallade kommunistlagarna år I930 var SDP det enda lagliga socialistiska alternativet i landet. För Ailis och Runars del betydde detta att deras politiska arbete utfördes inom ramen för SDP:s svenska partidistrikt, Finlands svenska arbetarförbund (FSA). I Vasa utökades familjen med sonen Ralf år 1936.

Aktivismen i Österbotten tog sig många former, av vilka den viktigaste var arbetet med tidningen Folkviljan. Tidningen utgavs för första gången i december 1936 med Georg Backlund som ansvarig utgivare. Det mesta av innehållet i Folkviljan bestod av översättningar

\footnotetext{
64. Högre Svenska Lantbruksläroverket i Åbo, Matrikel I9I6-1957, Åbo: Åbo Tidnings och Tryckeri Aktiebolag I966, s. 63; Högre Svenska Lantbruksläroverket 1916-1966, Åbo: Åbo Tidnings och Tryckeri Aktiebolag I96o, s. 39-4I; Salminen, Min amerikanska saga, s. II8.

65. Arkivpärlan: Aili Nordgren.

66. "Leitimon kartano", https://www.sotahistoriallisetkohteet.fi/app/sights/view/-/ $\mathrm{id} / 34$ (hämtad 26/ro 20I9).

67. Arkivpärlan: Aili Nordgren.
} 
av artiklar i nordiska, engelska och amerikanska publikationer. En förklaring till detta ligger i de kontakter och erfarenheter paren Nordgren och Backlund haft i New York. Åtminstone kände Backlundarna sig mer bekväma med de frågor och diskussioner som bedrevs internationellt, än med den finländska arbetarklassens historiska problem. Kontakterna till Nordamerika blir synliga också i det att tidningen publicerade läsarbrev från USA och Kanada, länder i vilka den också hade många prenumeranter. ${ }^{68}$

I december 1937 gav man ut ett så kallat Amerika-nummer av Folkviljan, i vilket läsarna i Österbotten kunde skicka hälsningar till släkt och vänner på andra sidan Atlanten. ${ }^{69}$ Genom att läsa Folkviljan kan man också se på vilka andra sätt paret Nordgren arbetade inom arbetarrörelsen. De var bland annat med om att sammankalla en studiecirkel som fick namnet Vårvindar, Runar valdes till ordförande och studieledare och Aili till vice ordförande. Studiecirkelns hoppingivande namn syftade på en önskan om en uppryckning inom den svenska arbetarrörelsen i Vasa såväl fackligt som politiskt. Den första sammankomsten ordnades i mars I938, och som ämne för studiecirkeln valdes medborgarkunskap. ${ }^{70}$ Bildningsarbete var överlag en uppgift som sågs som viktig inom arbetarrörelsen. Arbetarklassen behövde sin egen kunskap för att bryta den borgerliga samhällshegemonin. Upplysningsarbetet bedrevs också genom agitation vid olika tillställningar. Runar Nordgren var en omtyckt talare, och han blev inbjuden till olika möten i regionen. Ofta tog talen avstamp i upplevelserna i New York och Sovjetunionen. I sina tal uppmanade Runar till enighet inom arbetarrörelsen i stad och på landsbygd..$^{71}$ Även Aili deltog aktivt i socialistiska sammankomster under tiden i Vasa. Det spanska inbördeskriget engagerade socialister världen över och Aili var inget undantag. Hon deltog aktivt i insamlandet av pengar till de spanska

68. Huhta \& Wickström, "Rakkautta ja radikalismia New Yorkissa".

69. Folkviljan $4 / 12$ I937.

70. "Anton", "Studiecirkel bildad i Vasa", Folkviljan I9/3 1938.

71. "- j","Munsala-klubbens årsmöte”, Arbetarbladet, 28/2 I936;"X-ist”,"Närpesbrev", Folkviljan 20/2 I937;"R.N.","Socialdemokratisk förening bildad i Vassor, Kvevlaks", Arbetarbladet 30/I2 1937; "Anton", "Socialisterna i Vassor organiserar sig", Folkviljan 8/I 1938 . 
barnen tillsammans med flera andra FSA-kvinnor. ${ }^{72}$ Aili diktade också om barn och krig i Folkviljan:

En orsak.

Kriget fruktar jag ej

Men jag fruktar min kärlek

till barnen,

Min kärlek är alltför stark

och gör ont i mitt hjärta:

den gör mig svag

när jag tänker på barnen

Jag kysser min pojkes hår

med en känsla av skuld

Jag är girig - och rädd

och tar hungrigt ut på förhand

av det jag får,

som om var dag vore den sista

Därför förbannar jag kriget. ${ }^{73}$

Folkviljan tampades ständigt med ekonomiska svårigheter och blev ett tämligen kortvarigt projekt. Tidningen hade sannolikt inte heller klarat sig så länge den gjorde utan penninghjälp från Finlands kommunistiska parti, som i hemlighet bistod Folkviljan från Sovjetunionen via Sverige. Tidningens kryptokommunistiska linje vållade även politiska svårigheter och till slut förbjöd SDP att tidningen trycktes på partiets tryckeri i Vasa. Genom att låna pengar av sin bror i USA lyckades Georg Backlund finansiera en ny tryckpress, men Folkviljan måste ändå läggas ner sommaren 1939 på grund av penningbrist. ${ }^{74}$

Vid sidan om arbetet med Folkviljan kom Runar att engagera sig på andra sätt för det österbottniska lokalsamhället. Förutom agrolog-

72. Anna Bondestam \& Alf-Erik Helsing, Som en stubbe i en stubbåker. Finlands Svenska Arbetarförbund 1899-1974, Helsingfors: Finlands Svenska Arbetareförening 1978, s. 274 .

73. Aili Nordgren, "En orsak", Folkviljan 29/4 I939.

74. Huhta \& Wickström, "Rakkautta ja radikalismia New Yorkissa"; Bondestam \& Helsing, Som en stubbe, s. 267. 
utbildningen hade han avlagt en kurs för inspektörer och affärsföreståndare ordnad av Konsumtionsandelslagens centralförbund. Åren I935-1938 var han anställd som inspektör vid Försäkrings Ab Kansa och åren 1938-1945 vid Konsumtionsandelslagens centralförbund. ${ }^{75}$ Detta gjorde att han hade den kunskap och den drivkraft som behövdes då ett svenskspråkigt arbetarhandelslag i Närpes, Andelsaffären Ådalen, skulle bildas. Vid det konstituerande mötet i augusti 1938 var ett fyrtiotal intresserade närvarande. Mötet leddes av Runar som i en samtida tidningsnotis beskrivs som "en durkdriven agitator och flink affärsman”, drag som borgade för att han skulle göra Ådalen till en blomstrande affär. Kriget kom dock emellan och Runar blev inte långvarig i andelslaget. I stället drog familjen Nordgren än en gång upp bopålarna och flyttade bort från Vasa. ${ }^{76}$

FÖRFATTARSKAP OCH REVOLUTIONÄRT FAMILJEFÖRETAG PÅ Å L N D

I den radiointervju vi tidigare refererat till, där Aili blickade tillbaka på sitt liv, konstaterade hon att hon i ett skede var väldigt "trött på att vara sekreterare och skriva protokoll för jag ville skriva böcker". ${ }^{77}$ Aili blev medlem av Finlands svenska författareförening år 1943 och samma år publicerade Schildts förlag hennes första roman, Mörk längtan. ${ }^{78}$ Mörk längtan skildrar en evakuerad karelsk statarkvinnas färd från uppgivenhet till framtidstro. Enligt litteraturvetaren Thomas Warburton är romanens karelska folkförflyttningstematik unik inom den finlandssvenska litteraturen. ${ }^{79}$ Inspiration till sin berättelse om stataren Elina Kaara fick Aili bland annat under sitt år i Karelen. År I94I lämnade familjen Nordgren Vasa och flyttade till Åland. ${ }^{80}$

Efter den internationella succén med romanen Katrina (1936) hade

75. Ny Tid 6/6 I957.

76. Nils Nilsson, Andelsaffären Ådalen u.t. Io år, Helsingfors: Andelsaffären Ådalen I949, s. 5-6; "Brev från norrfångna landet", Arbetarbladet I6/9 I938.

77. Arkivpärlan: Aili Nordgren.

78. Stefan Nygård \& Henrika Tandefelt, Skrivandets villkor och gemenskap. Finlands svenska forfattareförening I9I9-20I9, Skrifter utgivna av Svenska litteratursällskapet i Finland 832, Helsingfors: Svenska litteratursällskapet i Finland 2019, s. 63.

79. Warburton, Attio år finlandssvensk litteratur, s. 265.

8o. Arkivpärlan: Aili Nordgren. 
Sally Salminen låtit bygga sig ett hus vid Kvarnboviken i Saltviks kommun, men hon vantrivdes i sin åländska villa och drog till Stockholm år 1939. I stället flyttade Aili och barnen in i Sallys stora hus. Där födde Aili ytterligare två barn, Magnus (194I) och Pehr Henrik (1944), medan Runar stred mot Sovjetunionen som luftvärnsman på Karelska näset. I en intervju för Åland berättade Aili att hon arbetade med Mörk längtan när barnen sov och att hennes litteraturintresserade man var hennes stora stöd som författare."Och ni skulle läsa de underbara brev han skickar till mig från fronten...!", citerade tidningen Aili. Däremot berättade Aili inte att hon var syster till tidens mest kända ålänning, Sally Salminen. ${ }^{81}$ Aili insisterade också på att hennes uppenbara släktskap med Sally inte skulle nämnas i reportaget, vilket tidningsredaktören hörsammade men inte kunde låta bli att omtala $i$ en senare artikel. ${ }^{82}$

Den I9 september 1944 slöt Finland och Sovjetunionen ett vapenstilleståndsavtal och Runar kom hem till sin familj på Åland. Det dröjde dock inte länge innan de förändrade politiska omständigheterna i Finland igen blev påtagliga i det Nordgrenska hemmet. Den 5 oktober 1944 anlände den i princip allierade, men i praktiken Sovjetstyrda, kontrollkommissionens ordförande generalöverste Andrej Zjdanov till Helsingfors. Zjdanov var en av Stalins närmaste män och hade bland annat lett införlivandet av Estland i Sovjetunionen sommaren I940 - spår som förskräckte i Finland hösten 1944. Det fanns dock många som såg framtiden an med tillförsikt. På ett slutet möte i Tölö i Helsingfors den I4-I5 oktober 1944 konstituerade sig Finlands kommunistiska parti (FKP), som därmed för första gången blev ett lagligt verkande parti i Finland. ${ }^{83}$ Trots freden med Sovjetunionen befann sig Finland i Stalins skugga och ett kommunistiskt maktövertagande var ett reellt scenario i samtiden. Inför denna nya situation i landets samhällsliv valde Aili och Runar att åter kasta sig in i klasskampen.

FKP bestämde sig för att försöka samla den finländska arbetarrörelsen i den kommunistiska frontorganisationen Demokratiska Förbun-

8I. Tor Torstensson, "Åländsk skaldinna skriver bygderoman", Åland 27/5 I943.

82. Tor Torstensson, "Aili Nordgren - Sally Salminens yngre syster", Vecko-Spegeln, 5/1944, s. I3.

83. Veli-Pekka Leppänen, Ohranasta oppositioon: kommunistit Helsingissä 1944-195I, Helsinki: Kansan Sivistystyön Liitto I994, s. 20. 
det för Finlands Folk (DFFF). Kommunisternas huvudmotståndare SDP skulle likvideras genom splittring och inlemmande i DFFF, där socialdemokratin slutligen skulle kvävas under kommunistiskt kommando. De finländska kommunisterna kom ut ur sina celler och upp ur underjorden för att, enligt planerna, äntligen ta Finland i besittning. Erövringen av Åland föll på Aili och Runar, den enda egentliga kader partiet hade i den borgerligt dominerade ögruppen. Det var en stor och socialt utmanande uppgift makarna Nordgren tog sig an som FKP:s ombud på det konservativa Åland. Deras tro på en folkdemokratisk framtid övertrumfade emellertid de tvivel de eventuellt hyste inför uppdraget att försöka omstörta den åländska samhällsordningen.

Aili och Runar blev i slutet av år 1944 medlemmar i DFFF och i början av år 1945 antogs de som medlemmar i FKP. ${ }^{84}$ Till skillnad från många andra som upptogs i partiet under de första efterkrigsåren behövde Aili och Runar inte redogöra för eventuella antisovjetiska snedsteg under krigsåren, särskilt i samband med vinterkriget, till vilket Runar inkallades kort före Moskvafreden i mars 1940. ${ }^{85}$ Det berodde antagligen på att de var finlandssvenskar, då rörelsen var i behov av engagerade svenskspråkiga medlemmar med erfarenhet av politiskt organisationsarbete.

År I945 flyttade familjen in till Mariehamn, där Aili och Runar försökte organisera de åländska arbetarna till motstånd mot öns förmenta fascister. Efter att Nordgrenarna flyttat ut sålde Sally huset i Kvarnbo. Detta upplevde Aili som ett svek och hon skällde ut sin syster, varefter kontakten dem emellan bröts för flera år. ${ }^{86}$ Runar erhöll indirekt anställning av FKP sommaren 1945 genom sin nya befattning som det kommunistdominerade Samfundet Finland-Sovjetunionens distriktssekreterare på Åland. Aili och Runar var givetvis också förgrundsfigurer i Samfundet Finland-Sovjetunionens åländska avdelning. Runar och Aili etablerade även med hjälp av bland andra Ailis syskon Rauha Åkerblom och Ruben Salminen en rad folkdemokratiska

84. "Biografiska uppgifter om Aili och Runar Nordgren", Samlingspärm för Aili Nordgren, Hmp F/ymp HK, Kadersektionens samling, FA.

85. Kimmo Rentola, Kenen joukoissa seisot? Suomalainen kommunismi ja sota 1937-1945, Porvoo: WSOY i994, s. I78; Militärstamkort för Runar Evald Nordgren.

86. Nordgren, "Min syster Sally", s. 87. 
föreningar runtom på Åland samt Mariehamns kommunistiska avdelning. Fram till flytten till Helsingfors fungerade Aili bland annat som sekreterare i FKP-avdelningen i Mariehamn och DFFF:s åländska kvinnoförening. ${ }^{87}$

Aili var DFFF:s enda åländska kandidat i 1945 års riksdagsval. Inför riksdagsvalet i mars höll Aili ett tal på Folkets hus i Haraldsby, där hon bland annat hävdade att kommunisterna ute i Europa blev bemötta med respekt för sina insatser i kriget medan fascisterna hatades "utan gräns". Annat var det på Åland där fascisterna fortsättningsvis hade svängrum och de som hade "demokratins seger" på sin sida smädades. Aili uppmanade därför till antifascistisk kamp mot en fiende som avslöjade sig genom sitt förhållningssätt mot folkdemokraterna:
Alla som angriper oss är fascisternas hantlangare, sann svensk de- mokrati har de ingen kännedom om. Därför bör vi oförskräckt gå vidare, utvecklingen kan ingen hejda och pionjärernas arbete har alltid varit tungt, först i historisk belysning har det ofta framträtt i sin fulla glans. ${ }^{88}$

Trots att Aili erhöll 600 röster i riksdagsvalet ville hon enligt historikern Gyrid Högman inte ställa upp i det åländska landstingsvalet sommaren 1945. I stället övertalade hon sin syster Rauha Åkerblom att kandidera för folkdemokraterna. ${ }^{89}$ Ailis ovilja berodde antagligen på att hon var fyrabarnsmor och att hon allra helst ville ägna sig åt sitt författarskap. Efter en livlig valkampanj där de åländska borgarna enligt Runar "vräkte hela sin förljugna propaganda mot folkdemokraterna", valdes Åkerblom in som landstingets enda kvinna och enda folkdemokrat..$^{90}$ Åkerbloms inval var Ailis och Runars största politiska seger på Åland. Runars och Ailis arbete på Åland uppskattades uppenbarligen av partiet, som snart kallade dem från Åland för

87. "Levnadsbeskrivning för Runar E. Nordgren", Samlingspärm för Runar Nordgren, Amp I/ymp, Kadersektionens samling, FA.

88. Aili Nordgren, citerad i "Från allmänheten: Mellersta Ålands Demokratiska Förening”, Åland 25/I 1945 .

89. Gyrid Högman, Den åländska kvinnans historia I700-1950, Mariehamn: Ålands kulturstiftelse I990, s. 457 .

9o. Runar Nordgren,”Arbetarrörelsen på Åland”, Folkets vår I947, s. 28. 
liknande uppdrag men nu med hela det svenskspråkiga Finland som verksamhetsfält. År 1947 flyttade familjen Nordgren till Helsingfors där Runar tillträdde tjänsten som svensk sekreterare i DFFF och Aili anställdes som svensk sekreterare i Samfundet Finland-Sovjetunionen. Ett nytt kapitel i Nordgrenarnas liv tog vid med positioner i kärnan av DFFF:s svenskspråkiga verksamhet. Förhoppningsvis får vi lov att återkomma till Ailis och Runars liv i det efterkrigstida Helsingfors i en framtida studie.

\section{ETT RÖRLIGT PAR I RÖTT}

Aili Salminen och Runar Nordgren växte inte upp i socialistiska hem, men erfor redan tidigt livets materiella villkor och människans utsatthet på marknaden, erfarenheter som de senare kom att ideologisera. Deras respektive resor till kapitalismens mönsterland USA föranleddes dock inte av revolutionsiver, utan av drömmen om förbättrade ekonomiska utsikter och oanade upplevelser i den ständigt expanderande amerikanska marknadsekonomin. Deras första möten med framtidslandet i väster var väldigt olika. Runar tog sig in illegalt och hans ekonomiska situation var prekär under hela hans tid i USA, medan den lagliga invandraren Aili så gott som omedelbart fick fotfäste på den amerikanska arbetsmarknaden och kunde ta del av det moderna konsumtionssamhällets rika utbud. På grund av sina ekonomiska bekymmer, sina sedan tidigare radikaliserade bröder och den misär han upplevde på New Yorks gator väcktes den unga Runar till insikt om kapitalismens krisskapande natur och den kommunistiska revolutionens nödvändighet.

För den ekonomiskt mer framgångsrika Aili var vägen till ideologisk väckelse en annan: den gick genom kärleken till Runar och den krets av ideologiskt entusiastiska finlandssvenskar de umgicks med. Aili mötte Runar på dansgolvet och tillsammans rörde de sig sedan med revolutionära visioner. För Runar och Aili och deras kamrater framstod Sovjetunionen som det nya drömlandet, men som vi sett var det inte i första hand kapitalismens kris i Amerika eller marxismleninismen i Sovjet som upptog den nygifta Runars privata tankar. Ovisshet och misströstan inför den riskfyllda resan och separationen från hustrun Aili ansatte Runar såväl innan som under färden mot 
Sovjetunionen. Dessvärre besannades flera av Runars farhågor. Han var snart hemma i Närpes, utmattad och längtande efter Aili på andra sidan Atlanten.

Ailis och Runars förhållande och kommunistiska övertygelse äventyrades dock inte av Runars misslyckade försök att etablera sig i Sovjet för deras gemensamma framtids skull. Tvärtom, de förblev trosvissa i sin kommunism och i sitt äktenskap. De var trots allt medlemmar i en världsrörelse som historiens lagar skulle leda till seger, hela mänskligheten till gagn. Aili fortsatte att försörja Runar från New York och när de äntligen återförenades i Finland fick hon följa med honom till Karelen, där de på nära håll bevittnade det finländska klassamhällets skrankor och russofobi. I Vasa återupptog de aktivt sitt arbete inom arbetarrörelsen tillsammans med sina gamla FUF-kamrater Georg och Aili Backlund. Under fortsättningskriget övervintrade familjen Nordgren på Åland medan pappa Runar försvarade Finland på Karelska näset. Hösten 1944 vädrade de som många andra finländska kommunister politisk vårluft - fascisterna som förpestat Finlands samhällsliv och störtat landet i ett förödande anfallskrig mot Sovjetunionen på Nazitysklands sida skulle äntligen bestraffas och utrensas. Finlands förtryckta massor skulle resa sig med DFFF och föra kommunisterna till makten. Tillsammans ledde Aili och Runar kampen mot (förment) fascism och för folkdemokrati på Åland, och även om revolutionen uteblev där liksom på fastlandet stod deras familjenätverk (NordgrenSalminen-Åkerblom) fast i sin radikala övertygelse.

De världshistoriska händelserna under första hälften av I9oo-talet, som oktoberrevolutionen I9I7 och tidens globala processer som Amerikaemigrationen och den stora depressionen, präglade Ailis och Runars liv. Men som Marx påpekade gör människorna själva sin historia även om de gör den under omständigheter de själva inte valt. Aili och Runar valde varandra och klasskampen för livet. De kommunistiska ikonerna på väggen hängde med till Helsingfors. Man kan jämföra med hur Ralf Nordgrens berättarjag Breng beskriver familjens sista byte av boningsort: "Lastbilen kör baklänges opp mot det nya huset. Helsingfors! [...] Vi bär in Marx och Engels och Lenin och Stalin. Min mor kommer med kaktusblommorna." 91

91. Nordgren, $M e d$, s. 47 . 